\title{
Semiquantitative mercury determination in fish: a tool for poisoning prevention*
}

\author{
ALLEGRA V. YALLOUZ ${ }^{1}$, TATIANA CALIXTO ${ }^{1}$ and SANDRA HACON ${ }^{2}$ \\ ${ }^{1}$ Coordenação de Química Analítica, Centro de Tecnologia Mineral, CETEM. \\ Avenida Ipê 900, Ilha da Cidade Universitária, 21941-590 Rio de Janeiro, RJ, Brasil \\ ${ }^{2}$ Departamento de Endemias Samuel Pessoa Escola Nacional de Saúde Pública / FIOCRUZ \\ Manguinhos 21041-210 Rio de Janeiro, RJ, Brasil \\ Manuscript received on September 24, 2001; accepted for publication on December 19, 2001; \\ presented by OtTo R. GotTLIEB
}

\begin{abstract}
Human exposure to mercury intoxication through contaminated fish ingestion has been well studied, mainly among Japanese population. The Brazilian population, particulaly in the Amazon region, is now in focus due to findings of fish contamination. Major health impacts caused by mercury affect mostly people who have a regular fish diet. A continuous checking for mercury content in the most consumed fish could prevent human intoxication. A simple, non-instrumental method to allow a continuous checking of the mercury content in fish was developed. Based on this method, we are proposing a prevention action where community agents can be trained to perform fish analysis. Technical Schools and Universities located nearby the affected areas would be in charge of quality control programs for the fish analysis as well as for the selection, training and update for operators.
\end{abstract}

Key words: mercury, fish, semiquantitative determination, poisoning prevention.

The major health impacts caused by mercury affect mostly individuals who have a regular fish diet. Human exposure to mercury intoxication through the ingestion of mercury contaminated fish has been well studied (Review: Harada 1995). The Brazilian population, particularly in the Amazon region, is now under scrutiny due to the confirmation of predictions (Salomons 1995) about fish contamination. Screening studies to evaluate the risk exposure of the population of Tapajós River Basin and Madeira River Basin analyzing carnivorous, herbivorous and omnivorous fish most consumed species by local population were done (San-

Correspondence to: Allegra V. Yallouz

E-mail: ayallouz@cetem.gov.br

*Presented at XXII RESEM (2000). tos LDN et al. 2000, Santos ECD et al. 2000, Bidone et al. 1997, Hacon et al. 1997. All authors above have concluded that carnivorous species accumulate more mercury specially when the fishes were collected at the dry season period (Hylander et al. 2000). The mercury accumulated by carnivorous fishes from Amazon region was mainly methylmercury, and represents 73-98\% from the total mercury content (Maurice-Bourgoin et al. 1999). This behavior is similar to the already described mechanism of mercury accumulation in non-tropical fishes (Newberne 1974). It was covincingly demonstrated that methylmercury is the most toxic form for humans (Harada 1995).

Studies of the effects of methylmercury exposure on human motor performance were performed 
in a village located on the banks of the Tapajós River in the Amazonian Basin, Brazil (Dolbec et al. 2000). The participants were fish eaters with about $60 \%$ of the total meals being composed by this kind of protein. Neurobehavioral manifestations of subtle neurotoxic effects on motor functions, associated with low-level methylmercury exposure were described.

These cases are only a small sample of the whole situation, showing that there is an urgent need to protect people from the Amazonian region from the high probability of intoxication through consumption of contaminated fish.

There are several analytical methods for mercury determination in biological samples. The most used method to determine mercury in fish samples is the cold vapor technique coupled to an Atomic Spectrometer or an Atomic Fluorescence equipment. However, it needs infrastructure, a specialized operator to perform the analysis and specific maintenance care that is not applicable everywhere, specially in small villages.

A simple non-instrumental method to allow a continuous checking of the mercury content in fish in small villages has been developed (Yallouz et al. 2000). The sample is acid digested and the mercury vapor released after chemical reduction with $\mathrm{SnCl}_{2}$. The mercury vapor is then collected on a detecting paper covered with an emulsion containing $\mathrm{Cu}_{2} \mathrm{I}_{2}$. A colored $\mathrm{Cu}_{2}\left[\mathrm{HgI}_{4}\right]$ complex is formed, with a characteristic color. The color intensity is proportional to the mercury concentration in the original sample. Although the method is semiquantitative, it may discriminate the fish samples in three concentration ranges, based on the World Health Organization (1990) recommendations, as can be seen in Table I.

The main advantages of this valuable method, a tool for environmental management, are its simplicity of operation and its utilization of low cost materials, allowing its use by non-specialist personnel everywhere.

The purpose of the present work is to present a prevention action based on the use of the semiquantitative method (CETEM 2000), including training programs for community agents, interlaboratory comparisons of analytical results and environmental education activities. The planned steps include:

1. The choice of an affected region, city or small village based on the literature screening data or on an evaluation of mercury content of the fish species most consumed in a historically polluted area.

2. The invitation of a Technical School or University located nearby the chosen area for a partnership with our center (CETEM). Local authorities must be involved. The planned activities for this Training Center are the training of the community agents, the control-checking analysis and the promotion of updating for the trained operators.

3. An evaluation of physical space conditions to build or adapt a small laboratory similar to the architecture project shown in Figure 1. The mini laboratory can be adapted in a room with dimensions of $3 m \times 3 m$, where there should be two different benches ( $1 \mathrm{~m}$ long each) for wet and dry preparations, and a fume hood. Electric and water supplies will be necessary.

4. A training program in the routine procedures for the team formed by a researcher that will be responsible for the Local Training Center and two technicians in our center (CETEM).

5. The adaptation of the semiquantitative method to the minilaboratory described in 3 .

6. The selection and training of addictional operators from the local community from small villages.

7. The quality control of analytical results achieved by regular interlaboratory comparisons with Cold Vapor Atomic Absorption Spectrometry (CVAAS) results for similar samples. 
TABLE I

Classification of fish by the semiquantitative method

\begin{tabular}{c|c}
\hline Classification & Hg content \\
\hline Safe for human consumption & Less than $300 \mathrm{ng} / \mathrm{g}$ \\
\hline Non safe for human consumption & More than $600 \mathrm{ng} / \mathrm{g}$ \\
\hline Safe for eventual consumption & Between 300 and $600 \mathrm{ng} / \mathrm{g}$ \\
\hline
\end{tabular}

8. The release of results reports for local authorities and researchers as a tool for environmental management.

9. The communication of the results to the community, using different communications techniques. Guidelines for safe human consumption of local fish will also be divulged to allow prevention action by the community.

The semiquantitative method validation for further accreditation by the INMETRO (the Brazilian Institute for Metrology) has been carryied out. Partnerships with Centro Federal de Educação Tecnológica de Química, CEFETEQ, located at Rio de Janeiro and the State University of Mato Grosso do Sul located in Alta Floresta are starting at the current year. CEFETEQ will adopt the semiquantitative method as a lecture regularly scheduled for the Technical Course of Chemistry, Food Science and Environmental Science. In the near future we will invite the other 80 Technical Schools from all over the country to join us.

\section{ACKNOWLEDGMENTS}

We thank CETEM Staff, CQA team, Priscila Marques, Dr Otto Richard Gottlieb and Maria Renata Borin. Thanks are also due to Conselho Nacional de Desenvolvimento Científico e Tecnológico (CNPq) for financial support.

\section{RESUMO}

A experiência da população japonesa relacionada à intoxicação por ingestão de peixe contaminado com mercúrio foi a base de muitos estudos. No Brasil, os peixes da região
Amazônica, têm apresentado evidências de contaminação, colocando em risco a saúde da população ribeirinha. O monitoramento contínuo do teor de mercúrio nos peixes desta região poderia evitar a intoxicação humana. Um método simples e não instrumental foi desenvolvido com o objetivo de permitir este monitoramento. Baseado neste método, está sendo proposto uma ação preventiva onde agentes comunitários bem treinados serão os analistas. Escolas Técnicas e Universidades localizadas próximas às áreas afetadas serão encarregadas do controle de qualidade das análises, assim como da seleção, treinamento e reciclagem dos operadores.

Palavras-chave: mercúrio, peixes, método semiquantitativo, prevenção de intoxicação.

\section{REFERENCES}

Bidone ED, Castilhos ZC, Souza TMC and Lacerda LD. 1997. Fish contamination and human exposure to mercury in the Tapajos river basin, Para state, Amazon, Brazil: A screening approach. Bull Environm Contamin Toxicol 59: 194-201.

CETEM. 2000. Available at http://WwW.cetem.gov.br/mercurio/semiquanti (presents the Program of semiquantitative mercury evaluation in fish-in Portuguese)

Dolbec J, Mergler D, Passos CJS, de Morais SS and LEBEL J. 2000. Methylmercury exposure affects motor performance of a riverine population of the Tapajos river, Brazilian Amazon. Internat Arch Occupat Environm Health 73: 195-203.

Hacon S, Rochedo ER, Campos R, Rosales G and LACERDA LD. 1997. Risk assessment of mercury in Alta Floresta. Amazon Basin Brazil. Water Air Soil Pollut 97: 91-105.

Harada M. 1995. Minamata disease: methylmercury. 



Fig. 1 - Minilaboratory architecture project. 1. Bench for drying preparation; 2. Fume hood; 3. Bench for humid preparation; 4. Space for color observation; 5. White plastic laminate; 6. Lamp; 7. Exaustor fan; 8. Tube of PVC; 9. Water reservoir 50L; 10. Sink.

Poisoning in Japan caused by environmental pollution. Crit Rev Toxicol 25: 1-24.

Hylander LD, Pinto FN, Guimaraes JRD, Meili M, Oliveira LJ and Silva EDE. 2000. Fish mercury concentration in the Alto Pantanal, Brazil: influence of season and water parameters. Sci Total Environm 261: 9-20.

Maurice-Bourgoin L, Quiroga I, Guyot JL AND MaLm O. 1999. Mercury pollution in the Upper Beni River, Amazonian Basin: Bolivia. AMBIO 28: 302- 
306.

Newberne, P. 1974. Mercury in fish: a literature review. Crit Rev Food Technol 5: 311-335.

SALOMONS W. 1995. Environmental impact of metals derived from mining activities - Processes, predictions, prevention. J Geochem Explor 52: 5-23.

Santos ECD, Jesus IM, Brabo ED, Loureiro ECB, Mascarenhas AFD, Eirich J, Camara VD and Cleary D. 2000. Mercury exposures in riverside Amazon communities in Para, Brazil. Environm Research 84: 100-107.
Santos LDN, Muller RCS, Sarkis JED, Alves CN, Brabo ED, Santos ED and Bentes MHD. 2000. Evaluation of total mercury concentrations in fish consumed in the municipality of Itaituba, Tapajos River Basin, Para, Brazil. Sci Total Environm 261: 1-8.

World Health Organization (WHO). 1990. Environmental health criteria for methyl mercury. International Program on Chemical Safety. 144p.

Yallouz AV, de Campos RC and Paciornik S. 2000. A low-cost non-instrumental method for semiquantitative determination of mercury in fish. Fres $\mathrm{J}$ Anal Chem 366: 461-465. 